\title{
The Effect of Promotion on the Decision to Choose a Higher Education through the Brand Image of Education
}

\author{
Umin Kango', Ari Kartiko², Muhammad Anas Ma`arif3 \\ DOI : $10.35445 /$ alishlah.v13i3.852
}

Article Info

Keywords:

Promotion;

Educationalimage;

Decision;

SEM

Kata kunci:

Promosi;

Citra Pendidikan;

Keputusan;

SEM

\begin{abstract}
Increasingly fierce competition from universities in getting new students requires universities to carry out marketing activities well, one of which is through promotion and formation of a good college image to influence the decisions of prospective new students in choosing a university. This research uses quantitative research, which consists of promotion variable (X1) as an exogenous variable, education image (Y1) as intervening variable, and decision to choose university (Y2) as an exogenous variable. This study uses primary data. It is obtained directly from respondents through questionnaires that have been tested for validity and reliability tests for each question item or statement that will be submitted to respondents. Data analysis technique to test the relationship between variables using structural equation modelling (SEM) using AMOS25. The sample of this study was 148 students of the Tarbiyah in an Institute. This study indicates that sales have a significant effect on choosing a college, and the image of education has a significant effect on college decisions. At the same time, the primary outcome variable can mediate the promotional education image variable on the decision to choose a college.
\end{abstract}

\begin{abstract}
Abstrak
Persaingan yang semakin ketat dari perguruan tinggi dalam mendapatkan mahasiswa baru menuntut perguruan tinggi untuk melakukan kegiatan pemasaran dengan baik salah satunya melalui promosi dan pembentukan citra perguruan tinggi yang baik sehingga mampu mempengaruhi keputusan calon mahasiswa baru dalam memilih universitas. Penelitian ini menggunakan penelitian kuantitatif yang terdiri dari variabel promosi (X1) sebagai variabel eksogen, citra pendidikan (Y1) sebagai variabel intervening dan keputusan memilih universitas (Y2) sebagai variabel eksogen. Penelitian ini menggunakan data primer. diperoleh langsung dari responden melalui kuesioner yang telah diuji validitas dan uji reliabilitasnya untuk setiap butir pertanyaan atau pernyataan yang akan disampaikan kepada responden. Teknik analisis data untuk menguji hubungan antar variabel menggunakan structural equation modeling (SEM) menggunakan AMOS25. Sampel penelitian ini adalah 148 santri Tarbiyah. Hasil penelitian ini menunjukkan bahwa promosi berpengaruh signifikan terhadap keputusan memilih perguruan tinggi dan citra pendidikan berpengaruh signifikan terhadap keputusan pergu ruan tinggi, sedangkan variable.
\end{abstract}

\footnotetext{
${ }^{1}$ Un iv ersitas Negeri Gorontalo, In donesia

Em ail: umin.kango@ung.ac.id

2 In stitut Pesantren KH. Abdul Chalim, Mojokerto, In donesia

Em a il: ari.kartiko5@gmail.com

3 In stitut Pesantren KH. Abdul Chalim, Mojokerto, In donesia

Em ail: anasdt16@gmail.com
} 


\section{INTRODUCTION}

Higher education is part of the education system in Indonesia as an advanced level of upper secondary education. Programs in higher education are not only Bachelor (S-1) but also diploma programs, professional education, masters (S-2), and even doctorate (S-3). Academic units that organize higher education are state universities and private universities. This college consists of universities, institutes, colleges, polytechnics, academies, and community academies.

Promotion in the education field is essential to conduct. Kango (2021) states that promotion influences new students interest of Madrasah Bertaraf Internasional (MBI) Pacet, Mojokerto. Factors that affect the interests of the new students includes internal factor and external. Internal factors include motivation, ideas and talents. External factors include teachers, family, friends, environment and equipment facilities and promotion.

Universities have functions including a) developing capabilities and shaping noble national character and civilization in order to educate the nation's life, b) developing an innovative, responsive, creative, skilled, competitive, and cooperative academic community through the implementation of the Tridharma, and c) developing Science and Technology by paying attention to and applying the values of Humanities. While the objectives are stated in Law no. 12 of 2012 concerning Higher Education, namely in Article 5. In-Law no. 12 of 2012, Article 5 mentions 4 (four) goals of higher education, namely as follows: a) developing the potential of students to become human beings who believe and fear God Almighty and have a noble character, are healthy, knowledgeable, capable, creative, independent, skilled, competent, and cultured for the benefit of the nation, b) the production of graduates who master the branches of science and technology to meet the national interest and increase the competitiveness of the nation, c) the production of science and technology through research that pays attention to and applies the values of humanities to be helpful for the progress of the nation, as well as the progress of civilization and the welfare of humanity and d) The realization of community service based on reasoning and research work that is useful in advancing the general welfare and educating the nation's life

Indonesia has many universities, so students who desire to continue their education have many choices to choose the college they will go to. Several types of research have been conducted about the promotion in education. Promotion can influence the decision in choosing a college, the image of the university, and the quality of education (Ahn et al., 2021; Sufirmansyah et al., 2021). Promotion is an activity to display the advantages of products or services owned by the general public, aiming to persuade customers to buy a product or service (Kotler, 2012; Kotler \& Keller, 2012). The promotions carried out by IKHAC include visiting schools, installing banners, brochures and using social media research by (Gusdiandika \& Sinduwiatmo, 2016), promotions consisting of advertising and direct marketing have an influence on school selection decisions by students of SMK 10 November Sidoarjo.

The image of the institution is formed through practical marketing activities. Universities must implement effective marketing in order to improve their image in front of consumers. A good image is expected to be able to influence consumer decisions in choosing universities. Research conducted by (Abuhassna et al., 2020; Yahya, 2020) shows results that the image of a university has a positive and significant influence on the decision to choose a university (Plungpongpan et al., 2016; R \& Ummah, 2019). According to (Drugan 2013; Fuchs, 1979), quality is a comprehensive description and characteristics of goods or services that show their ability to satisfy the expected needs. In education, the notion of quality includes the input, process, and output of education. Promotion is an essential part of marketing. This is because producers' promotion provides information on a product produced in the form of goods or services that aim to seduce. According to (Sherly et al., 2020; Swastha, 2008), the promotion has four main objectives as follows 1) behaviour modification, namely the behaviour and image of consumers assessing a product to make a purchase, can be done through promotion; 2) notifying, namely informing the target and 
the intended market segment about the company's offerings about a product; 3) persuade, namely, promotions influence buyer behaviour for a long time, then encourage consumers to make purchases; 4) Remind, namely to maintain the brand image in the hearts of consumers. It aims to maintain customer loyalty.

According to (Andrews \& Shimp, 2017), promotion consists of all marketing activities that try to stimulate the action of buying a product quickly or the occurrence of purchase in a short time. Promotional dimensions include physical promotion, promotion through traditional media, and promotion through digital. Physical promotions are usually held during special activities or events such as exhibitions, festival bazaars, or edu fairs. This physical promotion has several advantages, namely being able to touch or reach potential consumers and directly interact about the advantages and disadvantages of the products or services presented. However, it has drawbacks such as minimal potential customers because these activities are carried out at certain times, specific events, and certain environments in the school or campus area (Sharma et al., 2013; Spangler et al., 1997).

Promotion through traditional media is via print media such as magazines, tabloids, the like, and electronic media such as television, radio, and outside the room, such as banner ads or billboards. Promotion through this media is superior to physical promotion because it can reach a broader range of potential consumers. At the same time, it has a disadvantage in that the costs incurred are huge because it involves large media such as television (Plumeyer et al., 2019). Promotion through digital media is conducted by using the internet, social media and social networks. This method is the most widely used because almost everyone makes it possible to view products or services through cell phones or laptops. The advantages of this media have an extensive reach while the costs incurred are relatively low. The drawback of this promotion is that digital media has many competitors.

This study's indicators of choosing decisions are need initiative, information seeking, evaluating offers, accuracy in deciding, and psychological impact. The researchers formulate the problem as follows: 1) Does promotion significantly affect choosing a university? 2) Does the image of education have a significant effect on the decision to choose a university? 3) Does promotion have a significant effect on choosing a university through the image of education?. This research aims to determine the effect of promotion on the decision to choose a university, the influence of the image of education on choosing a university, and the effect of promotion on choosing a university through the image of education.

\section{METHODS}

This study uses quantitative data analysis techniques with survey techniques to test hypotheses between hypothesized variables or explain the effect of clause relationships between variables through hypothesis testing. Hypothesis testing based on Singarimbun aims to explain the causal relationship between the research variables and the hypothesis testing formulated. The implementation of this research is located at the Kh. Abdul Chalim in determining the research location was based on the number of applicants who registered as students at the Kh. Abdul Chalim, with a location located at the foot of Mount Welirang. The researchers examine the factors that influence the decision to choose a college.

The variables in this study can be classified as follows: 1) Exogenous variable: Promotion (X1) 2) Intervening Variable: Education Image (Y1). 3) Endogenous Variables: Decision to Choose university (Y2). The type of data in this study is primary data obtained directly from respondents using a questionnaire. The population in this study was all new students at IHKAC, Tarbiyah Faculty, on 2020/2021 academic year students. The sample is part of the number and characteristics possessed by the population. If the population is significant, and researchers cannot study everything in the population. According to Arikunto, if the subject is less than 100, it is better to take all of them. However, if the number of subjects is large or the research subjects are more 
than 100, the number of samples can be taken using the Slovin formula. Furthermore, Prasetya and Lina stated that the sample size taken could be represented, and then it could be calculated using the Slovin formula below.

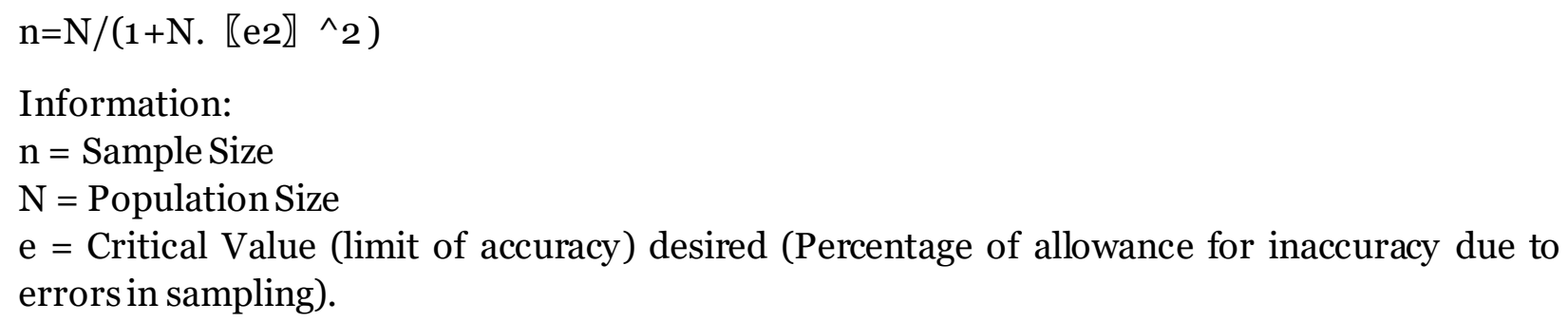

The sample is part of the number and characteristics possessed by the population. If the population is large, researchers cannot study everything in the population. Sugiyono (2016). The instrument in this research has been tested for validity and reliability. The validity test using Pearson's product-moment correlates the values obtained from each question item with the total value. Pearson's product-moment correlation index (r) can be found using the following formula:

$$
r=\frac{N\left(\sum X\right)-\left(\sum X \sum Y\right)}{\sqrt{\left[N \sum X^{2}-\left(\sum X\right)^{2}\right]-\left[N \sum Y^{2}-\left(\sum Y\right)^{2}\right]}}
$$

Information :

$\mathrm{r}=$ correlation coefficient

$\mathrm{X}=$ Item score

$\mathrm{Y}=$ Total score of items

$\mathrm{N}=$ number of samples (respondents)

Reliability test according to (Bentz \& Shapiro, 1998) (Malhotra, 2010), an instrument is said to be reliable if the Cronbach alpha value is greater than or equal to o.6. The Cronbach alpha formula is as follows:

$$
r_{i}=\left[\frac{k}{k-1}\right]\left[1-\frac{\sum a b^{2}}{\sigma t^{2}}\right]
$$

Information :

$\mathrm{r}_{1}$ : Instrument reliability

$\mathrm{k}$ : The number of questions

$\sum \mathrm{ab}^{2}:$ Sum of item variance

$\sigma t^{2}:$ Total variance

The measuring scale of this study uses a Likert scale of $1-5,1$ is used for answers strongly disagree (sts), 2 for answers that do not agree, 3 is neutral or undecided, 4 agrees (s) and 5 for answers strongly agree (ss). The data analysis technique of this research uses a quality model of the effect of exogenous variables on endogenous variables. To test the hypothesis proposed in this study, the SEM analysis technique is used with the AMOS (Analysis of Moment Structure) and SPSS (statistical product and service solutions) program packages version 25.

\section{FINDINGS AND DISCUSSION \\ Validity test}

The validity test was obtained by using the $\mathrm{r}$ product moment table, then determining $\mathrm{df}=\mathrm{n}$ 2 , that is $148-2=146$ with sig. $=0.05$, then the two-sided $r$ table is 0.159 , the condition is that if $r$ count is greater than $r$ table, then the statement item is valid, it can be seen in table 1 shows the results of the promotional validity test. Tcount is greater than Rtable, which means that all question items are declared valid. Table 2 shows the results of the educational image validity test. Rcount is greater than Rtable, which means that all variable question items are declared valid. 
Table 3 shows the results of the educational image validity test Rcount is greater than Rtable, which means that all question items or inconsistent statements are declared valid.

Tabel 1. Promotion validity test results

\begin{tabular}{lccc}
\hline \multicolumn{1}{c}{ Variable } & Rcount & Rtable & Explanation \\
\hline X1.1 & 0357 & 0,159 & Valid \\
X1.2 & 0,524 & 0,159 & Valid \\
X1.3 & 0,566 & 0,159 & Valid \\
X1.4 & 0,663 & 0,159 & Valid \\
X1.5 & 0,661 & 0,159 & Valid \\
X1.6 & 0,642 & 0,159 & Valid \\
X1.7 & 0,518 & 0,159 & Valid \\
X1.8 & 0,588 & 0,159 & Valid \\
X1.9 & 0,688 & 0,159 & Valid \\
X1.10 & 0,519 & 0,159 & Valid \\
X1.11 & 0,589 & 0,159 & Valid \\
\hline
\end{tabular}

Table 2. Image validity test results

\begin{tabular}{lccc}
\hline \multicolumn{1}{c}{ Variable } & RCount & Rtable & Explanation \\
\hline Y1.1 & 0,486 & 0,159 & Valid \\
Y1.2 & 0,511 & 0,159 & Valid \\
Y1.3 & 0,547 & 0,159 & Valid \\
Y1.4 & 0,527 & 0,159 & Valid \\
Y1.5 & 0,671 & 0,159 & Valid \\
Y1.6 & 0,572 & 0,159 & Valid \\
Y1.7 & 0,651 & 0,159 & Valid \\
Y1.8 & 0,643 & 0,159 & Valid \\
Y1.9 & 0,600 & 0,159 & Valid \\
Y1.10 & 0,666 & 0,159 & Valid \\
Y1.11 & 0,690 & 0,159 & Valid \\
\hline
\end{tabular}

Table 3. The results of the validity of the decision to choose a university

\begin{tabular}{lccc}
\hline \multicolumn{1}{c}{ Variable } & RCount & Rtable & Explanation \\
\hline Y2.1 & 0,536 & 0,159 & Valid \\
Y2.2 & 0,641 & 0,159 & Valid \\
Y2.3 & 0,599 & 0,159 & Valid \\
Y2.4 & 0,504 & 0,159 & Valid \\
Y2.5 & 0,687 & 0,159 & Valid \\
Y2.6 & 0,630 & 0,159 & Valid \\
Y2.7 & 0,585 & 0,159 & Valid \\
Y2.8 & 0,598 & 0,159 & Valid \\
Y2.9 & 0,650 & 0,159 & Valid \\
Y2.10 & 0,691 & 0,159 & Valid \\
Y1.11 & 0,626 & 0,159 & Valid \\
Y1.12 & 0,672 & 0,159 & Valid \\
Y1.13 & 0,610 & 0,159 & Valid \\
Y1.14 & 0,536 & 0,159 & Valid \\
\hline
\end{tabular}

Source: Processed primary data, 2021. 


\section{Reliability test}

The reliability test was carried out using Cronbach's alpha. If the Cronbach's alpha value > 0.60 , then the questionnaire was declared reliable. The results of the reliability test can be seen in table 4. The results of the Cronbach's alpha value of the promotion variable, educational image, and the decision to choose universities are greater $(>)$ than 0.60 . The question items from the three variables are declared reliable or can be used as a variable measuring instrument.

Table 4. Reliability Test

\begin{tabular}{lccc}
\hline \multicolumn{1}{c}{ Variable } & $\begin{array}{c}\text { Cronbach's } \\
\text { Alpha }\end{array}$ & $\begin{array}{c}\text { Standard } \\
\text { Reliability }\end{array}$ & Explanation \\
\hline Promotion(X1) & 0,742 & 0,60 & Reliable \\
$\begin{array}{l}\text { Education Image(Y1) } \\
\begin{array}{l}\text { Decisionto choose a } \\
\text { college(Y2) }\end{array}\end{array}$ & 0,853 & 0,60 & Reliable \\
\hline Source:Processed primary data, 2021 & 0,60 & Reliable \\
\hline
\end{tabular}

Source: Processed primary data, 2021

\section{Structural equation modelling test}

\section{Confirmatory Factor Analysis of Exogenous Variables}

Based on the value of the confirmatory factor analysis results, exogenous variables show the following results: The value of the promotion loading factor is the variable X1.1 $=0.84, \mathrm{X} 1.2=0.76$, and X1.3 $=0.82$. All loading factor values $>0.50$, then the three indicators used together present unidimensionality to become a construct that forms the Promotion variable.

\section{Confirmatory Factor Analysis Intervening Variables}

Based on the results of confirmatory factor analysis, the intervening variable shows the following results: The value of the education image loading factor is $\mathrm{Y} 1.1=0.42, \mathrm{Y} 1.2=0.65, \mathrm{Y} 1.3=$ $0.81, \mathrm{Y} 1.4=0,79$ and $\mathrm{Y} 1.5=0.81$. All loading factor values $>0.50$, then the five indicators used together present unidimensionality to construct the Education Image variable.

\section{Confirmatory factor analysis of endogenous variables}

Based on the confirmatory factor analysis results, endogenous variables show the following: The value of the loading factor for the decision to choose a university is the variable Y2.1 $=0.22$, $\mathrm{Y} 2.2=0.70, \mathrm{Y} 1.3=0.67$ and $\mathrm{Y} 1.4=0.83$ and $\mathrm{Y} 2.5=0.78$. All factor loading values $>0.50$, then the four indicators used together present unidimensionality to become the construct of the variable forming the decision to choose a university.

\section{Full SEM model technique}

This model is used to test the causality model that has been stated previously on various cause-and-effect relationships. The complete model analysis will show whether the model's suitability and the causality relationship built in the model being tested. The results of the Full Structural Model technique can be seen in picture 2.

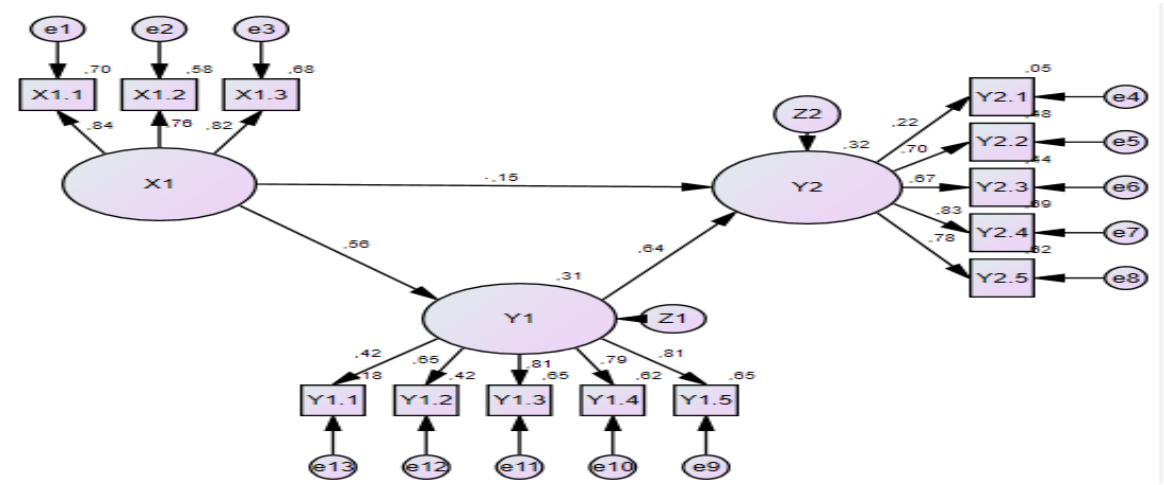

Figure 1. Full SEM Model 
The complete SEM model analysis results show the value of the standard regression coefficient (in SPSS, it is called "beta" or ). , The promotion coefficient on education image is 0.56, while the influence of education image on the decision to choose a university is 0.64 . The value of the Promotion coefficient on the decision to choose a university is 0.15.

The results of the suitability test and statistical test for the full SEM model can be seen in table 5:

Table 5. Full Fit Test Results of SEM Model

\begin{tabular}{|c|c|c|c|}
\hline $\begin{array}{l}\text { Goodness of fit } \\
\text { index }\end{array}$ & Cut off Value & Analysis Results & Model Evaluation \\
\hline Chi-Square & $\begin{array}{l}\text { Expeted to be } \\
\text { smaller than Chi- } \\
\text { Square }\left(X^{2} \text { table }\right) \text {, } \\
\text { with sig. } \alpha=0,05 \text {, } \\
\text { and } \mathrm{df}=101 \text { then } X^{2} \\
\text { table }=125,458 .\end{array}$ & 101,896 & Good \\
\hline Probability & $\geq 0,05$ & 0,001 & Good \\
\hline $\mathrm{CMIN} / \mathrm{DF}$ & $\leq 2.00$ & 1,643 & Good \\
\hline GFI & $\geq 0,90$ & 0,904 & Good \\
\hline TLI & $\geq 0,95$ & 0,936 & Good \\
\hline $\mathrm{CFI}$ & $\geq 0,95$ & 0,993 & Good \\
\hline
\end{tabular}

Source: Processed primary data, 2021.

The results of the model fit test show a chi-square value of $101.896<$ from the chi-square table 125.458 with sig $0.010>=0.05$, which means the covariance matrix between predictions and observations is the same. In contrast, other results show that CMIN/DF, TLI, CFI, and GFI values correspond to the specified cut-off value. Based on the results obtained, it can be concluded that the SEM model used can be categorized as good to describe the causality relationship of the factors used.

\section{Evaluation of the criteria of Goodness of fit}

Sample size

This study has a sample of 148 people, and the number is by the criteria; namely, the minimum number of samples is 100 people.

\section{Normality}

In order to examine the distribution of data whether the assumption of normality has been met so that the assumption of normality is met so that the data can be further processed by SEM modeling, it can be seen in table 6 :

Table 6. Normality Assumption Test Results

\begin{tabular}{|c|c|c|c|c|c|c|}
\hline Variable & $\min$ & Max & skew & c.r. & kurtosis & c.r. \\
\hline $\begin{array}{l}\mathrm{Y} 1.1 \\
\end{array}$ & 2,000 & $\overline{5,000}$ & ,243 & 1,206 & ,885 & 2,197 \\
\hline Y 1.2 & 2,000 & 5,000 & , 459 & 2,279 &, 384 &, 952 \\
\hline Y 1.3 & 000 & 5,000 & ,049 & ,241 & ,705 & 1,751 \\
\hline Y 1.4 & 000 & 5,000 & 138 & ,68 &,- 05 &,- 142 \\
\hline Y 1.5 & Doo & 5,000 & ,005 & , 027 &,- 233 &,- 578 \\
\hline Y 2.5 & 00 & 4,000 &,- 055 &,- 272 &,- 938 & $-2,330$ \\
\hline Y 2.4 & & 5,000 & , 103 & &,- 715 & $-1,775$ \\
\hline Y 2.3 & Doo & 5,000 &, 002 & ,008 & 1,420 & 3,526 \\
\hline Y 2.2 & 00 & 5,000 & ,020 & 100 & ,247 & ,614 \\
\hline Y 2.1 & & 4,000 & ,011 &, 0 &,- 206 &,- 512 \\
\hline $\mathrm{X} 1.3$ & 00 & 4,000 &,- 063 &,- 31 &,- 382 &,- 949 \\
\hline $\mathrm{X} 1.2$ & 00 & 5,000 & 292 & 1,448 & ,442 & 1,098 \\
\hline $\mathrm{X} 1.1$ & 2,000 & 5,000 & 245 & 1,215 & ,121 &, 300 \\
\hline Multivariate & & & & & $-1,780$ &,- 548 \\
\hline
\end{tabular}

Source: Processed primary data, 2021. 
The normality test results show that all indicators on the variables studied have a value of c.r. Between -2.58-2.58, so that all items in the variable are normally distributed.

\section{Outliers}

Based on the Mahalanobis distance table, it can be seen that the farthest observation point is the 32 nd point with a value of $\mathrm{Md}=26,830<48,267$. It can be concluded that if the farthest point is not an outlier, it can be concluded that all observation points are not outliers.

Observation number
32
4
13
38
11
99
108
8
129
110
91
2

$\begin{array}{rrr}\text { Mahalanobis d-squared } & \text { p1 } & \text { p2 } \\ 26,830 & , 013 & , 858 \\ 23,932 & , 032 & , 951 \\ 22,531 & , 048 & , 974 \\ 22,135 & , 053 & , 958 \\ 21,766 & , 059 & , 941 \\ 21,713 & , 060 & , 884 \\ 21,435 & , 065 & , 850 \\ 21,175 & , 070 & , 815 \\ 21,135 & .070 & , 720 \\ 20,880 & , 075 & , 685 \\ 20,646 & , 080 & , 648 \\ 20,596 & , 081 & , 547\end{array}$

Figure 2. Mahalanobis distance

\section{Hypothesis Testing}

Testing of the proposed hypothesis can be done based on the critical ratio value and sig level. contained in the regression weight, where the value of $\mathrm{cr} 2.00$ and sig. $=0.05$ as a condition for acceptance of the hypothesis. The result of the value of $\mathrm{cr}$ and the level of sig. Between hypothesized variables can be seen in table 7 .

Table 7. Hypothesis Test Results

\begin{tabular}{cccccccc}
\hline Endogen & & Exogen & Estimate & S.E & C.R & P & Keterangan \\
& & & & & & & \\
\hline Y1 & $<---$ & $\mathrm{X} 1$ & 0.037 & 0.018 & 2.076 & $* * *$ & Significance \\
Y2 & $<---$ & Y1 & 0.37 & 0.107 & 3.458 & $* * *$ & Significance \\
Y2 & $<---$ & $\mathrm{X} 1$ & 0.324 & 0.096 & 3.375 & $* * *$ & Significance \\
\hline
\end{tabular}

Source: Processed primary data, 2021.

Based on the results obtained, it can be proved as follows:

First Hypothesis Test Promotion affects the decision to choose a college. The critical ratio value obtained is more significant than two, which is a condition for accepting the hypothesis and p-value less than 0.05 is a condition for accepting the hypothesis. Based on this value, the first hypothesis, which suspects that promotion affects choosing a university, has a significant effect.

Test the second hypothesis Educational image affects the decision to choose a college. The critical ratio value of 3.458 , which is greater than 2 , is a condition for acceptance of the hypothesis, and the p-value is smaller than 0.05, which is also part of the requirements for accepting the hypothesis, so the second hypothesis which predicts that the image of education affects the decision to choose a college has a significant effect.

Third hypothesis test Promotion affects the decision to choose a college through the image of education. Testing the third hypothesis that promotion has a significant effect on choosing a university through the image of education can be seen through the direct relationship and the total effect in table 8 . 
Table 8. Effect Test Results

\begin{tabular}{cccc}
\hline Variable & $\mathrm{X} 1$ & $\mathrm{Y} 1$ & $\mathrm{Y} 2$ \\
\hline & Standardized Direct Effect & \\
Y1 & 0.037 & $\mathrm{o}$ & $\mathrm{O}$ \\
$\mathrm{Y} 2$ & 0.324 & 0.37 & $\mathrm{O}$ \\
& Standardized Total Effect & \\
Y1 & 0 & 0 & 0 \\
Y2 & 0.49 & 0.392 & 0 \\
\hline
\end{tabular}

Based on table 8, it can be seen that the total effect is more significant when juxtaposed with the direct effect, so the third hypothesis has been tested. Promotion affects the decision to choose a university.: Promotion has been proven in the decision to choose a college. It can be explained that IHKAC students know a lot about this college through physical promotions such as Edu fair events and direct visits to schools by the IHKAC new student admissions team. The next influencing factor is through the use of digital media. Internet and social media. Promotion through traditional media such as banners, banners, and billboards is still quite effective in attracting prospective new students. This variable research supports the research conducted by Gusdiandika and Sinduwiatmo (2012) at SMK 10 November Sidoarjo.

The image of education affects the decision to choose a university: Besides promoting the image of education, it has a significant effect on the decision to choose a university. The school's image through word of mouth is the most significant reflection, which means that the more people tell about the advantages of IHKAC, the better it will be in the community. In this case, customer experience, students who have carried out education at IHKAC, impacts IHKAC. The experience includes academic services, teaching and learning activities, and infrastructure. This variable research is in line with the research conducted by Yahya (2020), where the university's image positively affects the decision to choose education.

Promotion affects the decision to choose a university through the image of education: Based on the results of SEM analysis shows that the total effect of promotion on the decision to choose a university through the image of education is greater than the direct effect of promotion on the decision to choose a university. Based on these results, the image of education becomes a mediating variable that effectively helps prospective new students choose a college.

The role of the image of education as a mediation of promotion is the spread of information through word of mouth. The experience of students who are currently studying, the experience of alumni after studying will form an image of education which indirectly helps the role of promotion.

\section{CONCLUSION}

Based on the promotional SEM test results formed by physical promotion, promotion of traditional media and promotion through digital media affects students' decisions in choosing colleges, with the highest value of physical promotion, followed by promotion through digital media, and the last is promotion through traditional media. The image of education reflected through advertising, public relations, physical image, word of mouth, customer experience has a significant effect on choosing a university with indicators of need initiative, information seeking, evaluating offers, accuracy in deciding, and psychological impact in deciding. The image of education can play a role as a mediation of promotion on choosing a university. When viewed based on the results of the sem test, word to mouth gets the highest score, followed by customer experience, which means that providing the best service is the best promotion in influencing the decision to choose a college.

The limitations of this study are that it was conducted during the covid-19 pandemic so that researchers could not meet with respondents to conduct interviews, and the number of samples 
was relatively small, so the researchers suggested to further researchers to increase the number of samples and add variables related to education marketing.

\section{REFERENCES}

Abuhassna, H., Al-Rahmi, W. M., Yahya, N., Zakaria, M. A. Z. M., Kosnin, A. B. M., \& Darwish, M. (2020). Development of a new model on utilizing online learning platforms to improve students' academic achievements and satisfaction. International Journal of Educational Technology in Higher Education, 17(1), 1-23.

Ahn, I., Chiu, M. M., \& Patrick, H. (2021). Connecting teacher and student motivation: Studentperceived teacher need-supportive practices and student need satisfaction. Contemporary Educational Psychology, 64, 101950. https://doi.org/10.1016/j.cedpsych.2021.101950

Alwi, S., Che-Ha, N., Nguyen, B., Ghazali, E. M., Mutum, D. M., \& Kitchen, P. J. (2019). Projecting university brand image via satisfaction and behavioral response: Perspectives from UKbased Malaysian students. Qualitative Market Research: An International Journal, 23(1), 47-68. https://doi.org/10.1108/QMR-12-2017-0191

Andrews, J. C., \& Shimp, T. A. (2017). Advertising, promotion, and other aspects of Integrated Marketing Communications. Cengage Learning.

Bentz, V. M., \& Shapiro, J. J. (1998). Mindful inquiry in social research. Sage.

Chen, C.-F., \& Chen, C.-T. (2014). The Effect of Higher Education Brand Images on Satisfaction and Lifetime Value from Students' Viewpoint. The Anthropologist, 17(1), 137-145. https://doi.org/10.1080/09720073.2014.11891423

Drugan, J. (2013). Quality In Professional Translation: Assessment and Improvement. A\&amp;C Black.

Fuchs, J. H. (1979). Administering the Quality Control Function. Prentice-Hall.

Gusdiandika, R., \& Sinduwiatmo, K. (2016). Pengaruh Promosi Sekolah Terhadap Keputusan Siswa Dalam Pemilihan Smk Sepuluh Nopember Sidoarjo. Kanal: Jurnal Ilmu Komunikasi, 1(1), 27-38. https://doi.org/10.21070/kanal.v1i1.326

Kasali, R. (1994). Manajemen public relations: Konsep dan aplikasinya di Indonesia. Pustaka Utama Grafiti.

Kasali, R. (1998). Membidik pasar Indonesia: Segmentasi, targeting, dan positioning. Gramedia Pustaka Utama.

Kotler, P. (2012). Kotler On Marketing. Simon and Schuster.

Kotler, P., \& Keller, K. L. (2012). Marketing. Rebis.

Liou, J. J., \& Chuang, Y.-T. (2010). Developing a hybrid multi-criteria model for selection of outsourcing providers. Expert Systems with Applications, 37(5), 3755-3761.

Malhotra, N. K. (2010). Marketing research: An applied orientation (6. ed., global ed). Pearson Education.

Plumeyer, A., Kottemann, P., Böger, D., \& Decker, R. (2019). Measuring brand image: A systematic review, practical guidance, and future research directions. Review of Managerial Science, 13(2), 227-265. https://doi.org/10.1007/s11846-017-0251-2

Plungpongpan, J., Tiangsoongnern, L., \& Speece, M. (2016). University social responsibility and brand image of private universities in Bangkok. The International Journal of Educational Management, 3o(4), 571-591. https://doi.org/10.1108/IJEM-10-2014-0136

R, A. H. A., \& Ummah, B. (2019). Strategi Image Branding Universitas Nurul Jadid di Era Revolusi $\begin{array}{llll}\text { Industri } & 4.0 . & \text { TARBIYATUNA, } & \text { 59-81), }\end{array}$ https://doi.org/10.36835/tarbiyatuna.v12i1.352

Sharma, A. A., Rao, V. R., \& Popli, S. (2013). Measuring consumer-based brand equity for Indian business schools. Journal of Marketing for Higher Education, 23(2), 175-203. https://doi.org/10.1080/08841241.2013.866609 
Sherly, S., Halim, F., Butarbutar, M., SN, A., Sisca, S., Purba, B., Ferinia, R., Dewi, I. K., Hasyim, H., Sudarso, A., \& Purba, E. (2020). Pemasaran Internasional. Yayasan Kita Menulis.

Solomon, M. R., \& Stuart, E. W. (2003). Marketing: Real People, Real Choices. Prentice Hall.

Spangler, W. D., Dubinsky, A. J., Yammarino, F. J., \& Jolson, M. A. (1997). Impact of Personality on Sales Manager Leadership Style. Journal of Business-to-Business Marketing, 3(4), 2753.https://doi.org/10.1300/Jo33vo3no4_02

Sufirmansyah, S., Prameswati, L. N., Wati, D. T., \& Sulistyowati, E. (2021). Student's Preferences in Using Video-Based Learning Applications and Its Efficiency in Higher Education. Nazhruna: Jurnal Pendidikan Islam, 4(2), 272-283. https://doi.org/10.31538/nzh.v4i2.1474

Sumarsono, D. (2019). New Business Model for Hotel Industry Winning Competition. Gramedia Pustaka Utama.

Swastha, B., \& Irawan. (2008). Manajemen Pemassaran Modern. Liberty.

Yahya, M. (2020). Pengaruh Citra dan Promosi terhadap Keputusan memilih Perguruan Tinggi dengan Sikap sebagai Variabel Intervening pada Mahasiswa Sekolah Tinggi Ilmu Pertanian Agrobisnis Perkebunan. Repository USU. 